\title{
Investigation of the Antimicrobial Susceptibility Profile, Virulence Genes, and Epidemiologic Relationship of Clinical Salmonella Isolates
}

\section{Klinik Salmonella İzolatlarında Antimikrobiyal Duyarlılık Profilinin, Virülans Genlerinin ve Klonal Illişkinin Araştırılması}

\author{
(D) Yamaç TEKINTAȘ', (D) Fethiye Ferda YILMAZ², (D) Sabire Şöhret AYDEMIR³ , (D) Alper TÜNGER³ , (D) Mine HOŞGÖR-LIMONCU²* \\ İzmir Katip Çelebi University, Faculty of Pharmacy, Department of Pharmaceutical Microbiology, İzmir, Turkey \\ ${ }^{2}$ Ege University, Faculty of Pharmacy, Department of Pharmaceutical Microbiology, İzmir, Turkey \\ ${ }^{3}$ Ege University, Faculty of Medicine, Department of Medical Microbiology, İmir, Turkey
}

\begin{abstract}
Objectives: The objectives of this study were to investigate the epidemiologic relationship, prevalence of the beta-lactamase and virulence genes of clinical ampicillin-resistant Salmonella enterica.

Materials and Methods: In vitro ampicillin susceptibilities of 117 Salmonella enterica isolates obtained between 2011-2012 from Ege University Hospital, Bacteriology Laboratory of Medical Microbiology Department were examined using disc diffusion assays in accordance with the CLSI guidelines. The MIC levels in the ampicillin-resistant bacteria were determined using the broth microdilution method. The resistant strains were serotyped by the Public Health Institution. Epidemiologic relations of resistant strains were evaluated using ERIC-PCR. The presence of betalactamase genes and virulence factors were detected using PCR.

Results: The 117 S. enterica strains had ten isolates that were resistant to ampicillin, and the MIC range of ampicillin was found as $512-128 \mu \mathrm{g} / \mathrm{mL}$. Ampicillin-resistant strains were susceptible to nalidixic acid, ciprofloxacin, cefotaxime, sulfamethoxazole/trimethoprim. Four different serotypes were identified and isolates were grouped into seven clusters. Five isolates carried $b l a_{T E M}$, and two carried the bla $a_{C T X-M}$ gene. However, it was determined that $b l a_{S H V}$ and $b l a_{P E R}$ genes did not exist in these strains. Virulence genes invA, pipD, and sopB were found in all isolates. sifA, pefA, and sopE genes were found in seven, four, and three isolates, respectively.

Conclusion: Our data suggest that the rate of ampicillin resistance in S. enterica isolates was $8.5 \%$ in the two year period, but this ratio was generally lower than rates abroad. bla $a_{C T X-M}$ and $b l a_{T E M}$ genes could be responsible for ampicillin resistance. The bla $a_{S H V}$ gene, which is highly prevalent in our country, was not found in any strains. sopB and pipD genes, which might be associated with beta-lactam resistance, were found in all strains. It is also noteworthy that the three isolates containing the sopE gene, which is associated with epidemic cases, were of the same serotypes and epidemiologic clusters.
\end{abstract}

Key words: Salmonella enterica, beta-lactamase, virulence factors, ERIC-PCR

öz

Amaç: Bu çalışmanın amacı ampisilin dirençli klinik Salmonella enterica izolatlarında epidemiyolojik ilişkinin, beta-laktamaz ve virülans genlerinin araştırılmasıdır.

Gereç ve Yöntemler: Ege Üniversitesi Hastanesi, Tıbbi Mikrobiyoloji Anabilim Dalı, Bakteriyoloji Laboratuvarı'nda $2011-2012$ yıllarında izole edilen S. enterica kökenlerinin ampisilin duyarlııkları CLSı önerileri doğrultusunda disk difüzyon yöntemiyle değerlendirildi. Ampisilin dirençli izolatlardaki ampisilin MiK değerleri yine CLSI kriterlerine göre sıvı mikrodilüsyon yöntemiyle belirlendi. Dirençli kökenler Türkiye Halk Sağlığı Kurumu tarafından serotiplendirildi. Kökenlerin epidemiyolojik ilişsisi ERIC-PZR ile incelendi. Beta-laktamaz ve virülans genlerinin prevalansı PZR ile tespit edildi.

Presented in: In $25^{\text {th }}$ European Congress of Clinical Microbiology and Infectious Diseases (ECCMID) 25-28 April 2015, Copenhagen, Denmark, was presented.

*Correspondence: E-mail: minehosgorlimoncu@yahoo.com.tr, Phone: +90 5325681981 ORCID-ID: orcid.org/0000-0002-4892-8639

Received: 16.05.2017, Accepted: 13.07.2017

๑Turk J Pharm Sci, Published by Galenos Publishing House. 
Bulgular: İole edilen 117 S. enterica kökeninde 10 izolat ampisilin dirençli olarak saptandı ve bu izolatların ampisilin MiK aralığı 512-128 $\mu$ g/mL olarak belirlendi. İzolatlar nalidiksik asit, siprofloksasin, sefotaksim ve sulfametoksazol/trimethoprim antibiyotiklerine duyarlı bulundu. Dört farklı serotip belirlenirken, izolatlar ERIC-PZR'ye göre 7 farklı epidemiyolojik grupta yer aldı. Kökenlerin 5 tanesinde bla $a_{T E M}$, iki tanesinde bla $a_{C T X-M}$ geni saptandı. bla $a_{S H V}$ ve bla $a_{P E R}$ genleri hiçbir izolatta saptanmadı. invA, pipD, sopB virülans genleri tüm kökenlerde belirlenirken, sifA, pefA and sopE genleri sırasıyla üç, dört ve yedi kökende belirlendi.

Sonuç: Verilerimiz, S. enterica izolatlarında iki yıllık dönemde ampisilin direnç oranının \%8.5 olduğunu ortaya koymakla birlikte bu oranın genel olarak yurtdışındaki oranlardan düşük olduğu göze çarpmaktadır. bla $a_{C T X M}$ ve $b l a_{T E M}$ genleri ampisilin direncinden sorumlu olabilir. Ancak ülkemizde oldukça yüksek oranda saptanan $b l a_{S H V}$ genine hiçbir izolatta rastlanmamıștır. Beta-laktam direnci ile ilişkili olabileceği düşünülen $\operatorname{sop} B$ ve pipD genleri tüm suşlarda bulunmuştur. Ayrıca epidemik olgularla ilişkilendirilen sopE genini içeren üç izolatın aynı serotipe ve epidemiyolojik sınıfa ait kökenler olması dikkat çekicidir.

Anahtar kelimeler: Salmonella enterica, beta-laktamaz, virülans faktörleri, ERIC-PZR

\section{INTRODUCTION}

Salmonella spp. are some of the most important agents that lead to enteritis in the world. Additionally, they can lead to more critical health problems such as bacteremia and enteric fever. ${ }^{1}$ This group of bacteria include more than 2600 serotypes and consist of two species called S. enterica and S. bongori. S. enterica spp. are responsible for $99 \%$ of Salmonella infections and Salmonella Enteritidis and Salmonella Typhimurium are the most commonly isolated serotypes both in our country and in developed countries. ${ }^{2}$ Virulence factors, which responsible for invasion, extraintestinal spread, and intracellular survival, are encoded by genes located in the Salmonella pathogenicity island (SPI). Although some pathogenicity islands seem to be preserved in Salmonella genus, others are unique for certain serotypes. Based on presence of SPI and SPI features, Salmonella serotypes differ from each other in terms of adaptation in host cells, virulence factors, and severity of infections. $^{3}$

In most cases, resultant infections do not necessitate antibiotic treatment due to the self-limiting nature of disease. However, antibiotic treatment may be necessary for some situations such as invasive infections, advanced age, and immunosuppression. ${ }^{4}$ In such cases, ampicillin is widely used to treat Salmonella infections. ${ }^{5}$ Therefore, resistance to ampicillin has emerged and beta-lactam enzymes are primarily responsible of ampicillin resistance. ${ }^{6}$

The objectives of this study were to investigate betalactam resistance, the epidemiologic relationship, serotype distribution, and the prevalence of beta-lactamase genes, namely $b l a_{T E M}, b l a_{P E R^{\prime}} b l a_{C T X-M}, b l a_{S H V}$, and the virulence genes of clinical ampicillin-resistant S. enterica.

\section{EXPERIMENTAL}

\section{Antimicrobial susceptibility}

Salmonella enterica strains isolated in the Bacteriology Laboratory between 2010 and 2012 were used in our study. In vitro antibiotic susceptibilities of $117 \mathrm{~S}$. enterica isolates were examined using modified Kirby-Bauer disc diffusion assays in accordance with Clinical and Laboratory Standards Institute (CLSI). ${ }^{7}$ Standard ampicillin $(10 \mu \mathrm{g})$, cefotaxime (30 $\mu g)$, ciprofloxacin $(5 \mu g)$ sulfamethoxazole/trimethoprim (23, $75 / 1.25 \mu g$ ) (Oxoid, United Kingdom) discs were used to detect resistance. The other part of the study was performed in ampicillin- resistant strains. Minimum inhibitory concentration (MIC) values of the isolates were also determined using broth microdilutions in accordance with the recommendations of the CLSI and S. enterica ATCC 04059 was used as a control strain. ${ }^{8}$

\section{DNA isolation}

DNA isolation was performed for use in polymerase chain reaction (PCR) studies. For this purpose, isolates were suspended and homogenized in $200 \mu \mathrm{L}$ of sterile ultrapure water. The isolates were then incubated in a heat block at $95^{\circ} \mathrm{C}$ for $10 \mathrm{~min}$. Microtubes were centrifuged at 13,000 rpm for 5 min. The supernatants were transferred to sterile microtubes and stored at $-20^{\circ} \mathrm{C}$ for use in PCR studies.

\section{Serotypes and epidemiologic relation}

The strains were serotyped by the Turkish Public Health Agency, National Microbiology Reference Laboratory. The epidemiologic relations of the isolates were analyzed using PCR with enterobacterial repetitive intergenic consensus (ERIC)-2 and ERIC-1R primers. ${ }^{9}$ To evaluate similarity between these isolates, Jaccard coefficients were derived from the banding patterns. Dendrograms were constructed according to the unweighted pair group with arithmetic mean method, using Jaccard coefficients and MEGA software, version 4.0.

\section{Beta-lactamase genes}

bla $a_{\mathrm{CTX}-\mathrm{M},} \quad b l a_{\mathrm{TEM}}, \quad b l a_{\mathrm{SHV}}, \quad b l a_{\mathrm{PER}}$ genes were determined using primers targeting the relevant regions ${ }^{10-12}$ using the conventional multiplex PCR method. PCR assays were run in $25 \mu \mathrm{L}$ amplification mixtures composed of $5 \mu \mathrm{L}$ bacterial DNA template, $2.5 \mu \mathrm{L}$ Taq buffer, $1.5 \mathrm{mM} \mathrm{MgCl}, 200 \mu \mathrm{M}$ dNTP, 30 pmol forward and reverse primers, and $1.25 \cup$ Taq polymerase.

\section{Virulence genes}

Six different virulence genes were analyzed in two different multiplex PCR reactions, using primers targeting the relevant genes. ${ }^{13,14}$ For this purpose, a $5-\mu \mathrm{L}$ bacterial DNA template, 2.5 $\mu \mathrm{L}$ Taq buffer, $1.5 \mathrm{mM} \mathrm{MgCl}, 200 \mu \mathrm{M}$ dNTP, 20 pmol forward and reverse primers, $1.25 \cup$ Taq polymerase were prepared in $25 \mu \mathrm{L}$ volume.

\section{RESULTS}

As a result of the disc diffusion test, ten (8.5\%) out of $117 \mathrm{~S}$. enterica isolates were detected as resistant to ampicillin. These resistant strains were susceptible to ciprofloxacin, cefotaxime, 
sulfamethoxazole/trimethoprim. The ampicillin MIC range of the isolates was found as $512-128 \mu \mathrm{g} / \mathrm{mL}$. The strains were divided into seven different clusters based on ERIC-PCR results. The detected serotypes were as follows; S. Enteritidis $(n=5)$, S. Infantis $(n=2), S$. Typhimurium $(n=1)$, and S. Corvallis $(n=1)$. One isolate could not be serotyped. Five strains involved bla $a_{\text {TEM }}$ genes, two strains contained bla $a_{\text {CTX-M }}$ genes. bla $a_{\mathrm{PER}}$ and bla $a_{\mathrm{SHV}}$ genes were not encountered. InvA, pipD, sopB, which are virulence genes, were detected in all strains, sif $A$ in seven, pef $A$ in four, and sopE in three strains.

\section{DISCUSSION}

The Salmonella genus comprises many members. Some Salmonella serotypes are known to be more commonly isolated. In light of this information and existing data; the most frequently isolated Salmonella serotype is known to be S. Enteritidis. ${ }^{15}$ In our study, five of the ampicillin resistant Salmonella strains were determined as S. Enteritidis. In 2014, Maraki and Papadakis ${ }^{4}$ determined S. Enteritidis as the most commonly isolated serotype of Salmonella (37.3\%). In another study by Ozdemir and Acar, ${ }^{16} \mathrm{~S}$. Enteritidis was determined as the most commonly isolated serotype from Salmonella isolates collected from 4 different provinces of Turkey. Our results show consistency with the literature.

Serotyping is the basic phenotypic method for epidemiologic investigation of isolates. Nonetheless, it cannot differentiate strains of the same serotype. Genotypic methods such as pulsed-field gel electrophoresis (PFGE), ERIC-PCR, and repetitive element palindromic PCR can distinguish the strains more effectively. Although PFGE is the gold standard method for fingerprinting, due to the lack of equipment and to avoid protocols lasting four-five days, a simpler method of ERICPCR was preferred. ${ }^{17,18}$ In our study, strains were divided into 7 unrelated clusters using ERIC-PCR with an acceptable $(\geq 0.90)$ discriminatory index value of 0.92 . When the literature and data obtained in this study are evaluated, ERIC-PCR is considered to be a useful and easily applicable method for genotyping of strains.

Recently, Salmonella strains have shown resistance against many antibiotic groups. Ampicillin, which is a member of the beta-lactam antibiotics, is the first-line agent used in the treatment of Salmonella infections. Salmonella strains that are resistant to ampicillin and other beta-lactams pose a risk for public health. ${ }^{5}$ According to our disc diffusion results, ampicillinresistant strains are susceptible to other groups of antibiotics such as ciprofloxacin, cefotaxime, and sulfamethoxazole/ trimethoprim.

According to data gained abroad, the rate of ampicillin resistance against Salmonella varies from one country to another. As for studies abroad; in India, ampicillin resistance in S. enterica isolates was detected as $25 \%$ in $2011 . .^{19}$ It was $33 \%$ in Salmonella isolated from children in Cambodia, ${ }^{20} 46 \%$ in Korea, ${ }^{21} 55 \%$ in Spain, ${ }^{22}$ and $8 \%$ in the United States. ${ }^{23}$ In Turkey, there have been a few studies of clinical Salmonella strains that were isolated from children's hospital. The rate of ampicillin resistance in Salmonella strains were determined as 25.8\% in $2012,{ }^{24}$ and $19 \%$ in $2014 .{ }^{25}$ However, resistance rates were higher than in our study. According to the our knowledge, the stress of starting antibiotic treatment empirically in pediatric patients, before culture results, might be responsible for higher ampicillin resistance rates than in our study.

In our study, five isolates with $b l a_{\text {TEM }}$ genes and two isolates with bla $a_{\text {CTX-M }}$ genes were found. bla $a_{\text {СTX-M }}$-positive isolates were in the S. Ifantum serotype. Four of five $b a_{\text {TEM }}$ gene positive isolates were in S. Enteritidis serotype, and the remaining strain was in S. Typhimurium. Although the most common beta-lactamase genes of Salmonella isolates are variants of bla $a_{\mathrm{CTX}-\mathrm{M}}$ and $b l a_{\mathrm{SHV}}{ }^{26}$ no bla $a_{\mathrm{SHV}}$ gene was found in isolates used in our study. Different rates of beta-lactam resistance genes were reported in studies conducted abroad. Among 20 ampicillin-resistant Salmonella isolates, beta-lactamase genes were found to be bla $a_{\mathrm{SHV}} 100 \%$, $b l a_{\text {TEM }} 85 \%, b l a_{\text {СTX-M }} 5 \%$ in one study; ${ }^{2}$ and in 90 beta-lactamresistant strains in Spain it was $b / a_{\text {TЕM }} 22 \%$, and bla $a_{\text {СТХ-M }} 1 \% .{ }^{22}$ In the Netherlands, a study with 34 Salmonella strains isolated from humans and the environment, Hasman et al. ${ }^{6}$ detected the bla $a_{\text {TEM }}$ gene in 19 (55\%) strains, the bla $a_{\text {CTX-M }}$ gene in six $(17 \%)$, and the bla $a_{\mathrm{SHV}}$ gene in three (8\%) strains; all 34 isolates were found to be resistant to penicillin. A study conducted on $\mathrm{S}$. Typhimurium in 2011 in Turkey detected $23 \%$ bla $_{\text {CTX-M }}$ gene, $76 \% b l a_{\mathrm{TEM}}$ gene, and $100 \%$ bla $a_{\mathrm{SHV}}$. The $b l a_{\mathrm{PER}}$ gene could not be detected in any isolates ${ }^{27}$.

Salmonella bacteria carry many different and complex virulence factors. Investigating the presence of virulence factors coded as different pathogenicity islands will guide us in the matter of discovering Salmonella pathogenesis. Our study is thought to be the first in Turkey to investigate the virulence factors of Salmonella, at least three virulence factors were detected in all strains. The invA gene was determined in all isolates involved in this study, and it was present independent from conditions such as serotype and resistance genes. Dione et al. ${ }^{26}$ detected the invA gene in $99.5 \%$ of strains in a study. Another study conducted by Smith et al..$^{5}$ in 2010 encountered the invA gene in all. The determination of high levels of the invA gene in different regions despite different serotypes and antimicrobial susceptibility profiles indicated the existence of a preserved region in this gene. Thus, the idea of using this gene for rapid diagnosis of Salmonella with PCR as a target region has arisen, and this idea has led to studies with positive outcomes. ${ }^{28}$

Generally, the sopE gene, which has been shown to have the lowest prevalence, has been associated with epidemic cases. $^{26,29}$ In our study, the presence of three strains that involve this gene in the same group according to ERIC-PCR and their isolation in a short period of time indicated that they may have been isolated after a community- onset epidemic.

Hughes et al. ${ }^{14}$ detected pipD and sopB genes in all strains and these virulence factors have been associated with enteritis. The detection of these genes in all resistant isolates indicated a possible relationship between these virulence factors and resistance. A study conducted by Dione et al. ${ }^{26}$ and our data gave similar results. Also, Khoo et al. ${ }^{30}$ detected alterations 
in beta-lactam resistance as a result a mutations created in these two genes. Although our study did not directly show the relationship between resistance and virulence factors, it showed the necessity for further extensive studies about the relationship between these two factors.

The pefA gene, which was detected in four strains at the present study, may be located on the same or different plasmid with different virulence ( $s p v$ ) genes. Only a fraction of Salmonella serotypes carries different-sized plasmids, which are known as serovar specific. However, it is known that not every plasmidcarrying serotype includes the pefA gene. Therefore, it is thought that the pefA gene has a lower prevalence compared with other virulence factors. ${ }^{31}$ Hughes et al. ${ }^{14}$ showed that only three isolates out of 32 involved the pefA gene. Skyberg et al. ${ }^{13}$ performed a study on Salmonella of different serotypes, the pefA gene was found in 11 of 152 strains, and it was only present in serotypes of S. Typhimurium and S. Enteritidis. The low prevalence of the pefA gene in our study is compatible with the results of the other studies. Additionally, three out of four pefA gene-carrying strains belonged to the S. Enteritidis serotype, and this result is also consistent with the literature data.

The sifA gene, which enables the sustained vitality of Salmonella bacteria in macrophages, was detected in seven strains in our study. Hur et al. ${ }^{32}$ detected the sifA gene in all of 42 strains. Skyberg et al. ${ }^{13}$ determined the sifA gene in 137 out 158 isolates. The existence rate of the sif $A$ gene in this study was similar to that of studies conducted abroad.

\section{CONCLUSION}

As a result, in light of studies both in our country and abroad, it is known that there are Salmonella strains that are resistant to antimicrobial agents, some of which are beta lactamaseproducing. Further investigation on the resistance and virulence profiles of Salmonella strains will enable us to better understand the pathogenesis of infections and to be able to take better measurements and give proper treatments.

\section{ACKNOWLEDGEMENTS}

We are grateful to the UEPLA team for the serotyping of the strains as a surveillance program of the Public Health Institution of Turkey.

Conflict of Interest: No conflict of interest was declared by the authors.

\section{REFERENCES}

1. Vatopoulos AC, Mainas E, Balis E, Threlfall EJ, Kanelopoulou M, Kalapothaki V, Malamou-Lada H, Legakis NJ. Molecular Epidemiology of Ampicillin-Resistant Clinical Isolates of Salmonella Enteritidis. J Clin Microbiol. 1994;32:1322-1325.

2. Archambault M, Petrov P, Hendriksen RS, Asseva G, Bangtrakulnonth A, Hasman H, Aarestrup FM. Molecular Characterization and Occurrence of Extended-Spectrum $\beta$-Lactamase Resistance Genes among Salmonella enterica Serovar Corvallis from Thailand, Bulgaria and Denmark. Microb Drug Resist. 2006;12:192-198.
3. Sırıken B. Salmonella Patojenite Adaları. Mikrobiyol Bul. 2013;47:181-188.

4. Maraki S, Papadakis IS. Serotypes and Antimicrobial Resistance of Human Nontyphoidal Isolates of Salmonella enterica from Crete, Greece. Interdiscip Perspect Infect Dis. 2014;2014:256181.

5. Smith KP, George J, Cadle KM, Kumar S, Aragon SJ, Hernandez RL, Jones SE, Floyd JL, Varela MF. Elucidation of Antimicrobial Susceptibility Profiles and Genotyping of Salmonella enterica Isolates from Clinical Cases of Salmonellosis in New Mexico in 2008. World J Microbiol Biotechnol. 2010;26:1025-1031.

6. Hasman H, Mevius D, Veldman K, Olesen I, Aarestrup FM. BetaLactamases among extended-spectrum beta-lactamase (ESBL)resistant Salmonella from poultry, poultry products and human patients in The Netherlands. J Antimicrob Chemother. 2005;56:115-121.

7. CLSI. Clinical and Laboratory Institute (2013) Performance Standarts for Antimicrobial Susceptibility Testing; Twenty-Third Informational Supplement CLSI document M100-S23. Clinical and Laboratory Standarts Institute, Wayne. 2013:44.

8. CLSI. Clinical and Laboratory Institute (2013) Performance Standarts for Antimicrobial Susceptibility Testing; Twenty-Third Informational Supplement CLSI document M100-S23. Clinical and Laboratory Standarts Institute, Wayne. 2013:142.

9. Versalovic J, Koeuth T, Lupski JR. Distribution of repetitive DNA sequences in eubacteria and application to fingerprinting of bacterial genomes. Nucleic Acids Res. 1991;19:6823-6831.

10. Mugnaioli C, Luzzaro F, De Luca F, Brigante G, Perilli M, Amicosante G, Stefani S, Toniolo A, Rossolini GM. CTX-M-type extended-spectrum $\beta$ lactamases in Italy: Molecular epidemiology of an emerging countrywide problem. Antimicrob Agents Chemother. 2006;50:2700-2706.

11. Claeys G, Verschraegen G, de Baere T, Veneechoutte M. PER-1 $\beta$-lactamase-producing Pseudomonas aeruginosa in an intensive care unit. J Antimicrob Chemother. 2000;1:924-925.

12. Taşli H, Bahar IH. Molecular Characterization of TEM- and SHVDerived Extended-Spectrum Beta-Lactamases in Hospital-Based Enterobacteriaceae in Turkey. Jpn J Infect Dis. 2005;58:162-167.

13. Skyberg JA, Logue CM, Nolan LK. Virulence genotyping of Salmonella spp. with multiplex PCR. Avian Dis. 2006;50:77-81.

14. Hughes LA, Shopland S, Wigley $P$, Bradon $H$, Leatherbarrow $A H$, Williams NJ, Bennet M, de Pinna E, Lawson B, Cunningham AA, Chantrey J. Characterisation of Salmonella enterica serotype Typhimurium isolates from wild birds in northern England from 2005-2006. BMC Vet Res. 2008;4:4.

15. Osawa K, Shigemura K, Shimizu R, Kato A, Kimura M, Katayama Y, Okuya Y, Yutaka S, Nishimoto A, Kishi A, Fujiwara M, Yoshida H, lijima $Y$, Fujisawa M, Shirakawa T. Antimicrobial resistance in Salmonella strains clinically isolated in Hyogo, Japan (2009-2012). Jpn J Infect Dis. 2014;67:54-57.

16. Ozdemir K, Acar S. Plasmid profile and pulsed-field gel electrophoresis analysis of Salmonella enterica isolates from humans in Turkey. PloS One. 2014;9:e95976.

17. Bhowmick PP, Srikumar S, Devegowda D, Shekar M, Darshanee Ruwandeepika HA, Karunasagar I. Serotyping \& molecular characterization for study genetic diversity among seafood associated nontyphoidal Salmonella serovars. Indian J Med Res. 2012;135:371-381.

18. Peters MT. Pulsed-Field gel electrophoresis for molecular epidemiology of food pathogens. Methods Mol Biol. 2009;551:59-70 
19. Parvathi A, Vijayan J, Murali G, Chandran P. Comparative virulence genotyping and antimicrobial susceptibility profiling of environmental and clinical Salmonella enterica from Cochin, India. Curr Microbiol. 2011;62:21-26.

20. Meng CY, Smith BL, Bodhidatta L, Richard SA, Vansith K, Thy B, Srijan A, Serichantalergs O, Mason CJ. Etiology of diarrhea in young children and patterns of antibiotic resistance in Cambodia. Pediatr Infect Dis J. 2011;30:331-335.

21. Lee JY, Kim JA, Jeong HS, Shin JH, Chang CL, Jeong J, Cho JH, Kim MN, Kim S, Kim YR, Lee CH, Lee K, Lee MA, Lee WG, Shin JH, Lee JN. Serotyping and antimicrobial susceptibility of Salmonella spp.: nationwide multicenter study in Korea. Jpn J Infect Dis. 2013;66:284-289.

22. de Toro M, Sáenz Y, Cercenado E, Rojo-bezares B, García-campello M, Undabeitia E, Torres C. Genetic characterization of the mechanisms of resistance to amoxicillin / clavulanate and third-generation cephalosporins in Salmonella enterica from three Spanish hospitals. Int Microbol. 2011;14:173-181.

23. Crump JA, Medalla FM, Joyce KW, Krueger AL, Hoekstra RM, Whichard JM, Barzilay EJ; Emerging Infections Program NARMS Working Group. Antimicrobial resistance among invasive nontyphoidal Salmonella enterica isolates in the United States: National Antimicrobial Resistance Monitoring System, 1996 to 2007. Antimicrob Agents Chemother. 2011;55:1148-1154.

24. Ince OT, Yalçin SS, Yurdakök K, Ozmert EN, Aydin A, Bariş Z, Gür D. Salmonella gastroenteritis in children (clinical characteristics and antibiotic susceptibility): comparison of the years 1995-2001 and 20022008. Turk J Pediatr. 2012;54:465-473.

25. Bayhan GI, Tanir G, Levent B, Özkan Ş, Güleșen R, Timur ÖM. Serotype distribution, antibiotic resistance and clinical features of Salmonella infections. Turkiye Klinikleri J Med Sci. 2014;34:137-144.

26. Dione MM, Ikumapayi U, Saha D, Mohammed NI, Adegbola RA, Geerts $\mathrm{S}$, leven M, Antonio M. Antimicrobial resistance and virulence genes of non-typhoidal Salmonella isolates in The Gambia and Senegal. J Infec Dev Ctries. 2011;5:765-775.

27. Ağin H, Ayhan FY, Gülay Z, Gülfidan G, Yaşar N, Eraç B, Devrim I. The evaluation of clusters of hospital infections due to multidrug-resistant Salmonella enterica serovar Typhimurium in the neonatal unit: a two-year experience. Turk J Pediatr. 2011;53:517-521.

28. Shanmugasamy M, Velayutham T, Rajeswar J. Inv A gene specific PCR for detection of Salmonella from broilers. Vet World. 2011;4:562-564.

29. Mirold S, Rabsch W, Rohde M, Stender S, Tschäpe H, Rüssmann H, Igwe E, Hardt WD. Isolation of a temperate bacteriophage encoding the type III effector protein SopE from an epidemic Salmonella Typhimurium strain. Proc Natl Acad Sci U S A. 1999;96:9845-9850.

30. Khoo CH, Sim JH, Salleh NA, Cheah YK. Pathogenicity and phenotypic analysis of $\operatorname{sop} B, \operatorname{sop} D$ and pipD virulence factors in Salmonella enterica serovar Typhimurium and Salmonella enterica serovar Agona. Antonie Van Leeuwenhoek. 2015;107:23-37.

31. Rotger R, Casadesús J. The virulence plasmids of Salmonella. Int Microbiol. 1999:2:177-184.

32. Hur J, Choi YY, Park JH, Jeon BW, Lee HS, Kim AR, Lee JH. Antimicrobial resistance, virulence-associated genes, and pulsedfield gel electrophoresis profiles of Salmonella enterica subsp enterica serovar Typhimurium isolated from piglets with diarrhea in Korea. Can J Vet Res. 2011;75:49-56. 